\title{
Correction: Accelerated in vitro model for occlusion of biliary stents: investigating the role played by dietary fibre
}

Surwase S, Balakrishnan H, Acharya SK, et al. Accelerated in vitro model for occlusion of biliary stents: investigating the role played by dietary fibre. BMJ Innovations 2018;4:39-45. doi:10.1136/bmjinnov-2017-000209

This article was previously published with an error.

In the second paragraph of Materials and methods section it is written 'Bile-resistant Escherichia coli from the strain ATCC2931 was developed by subculturing it in the aforementioned 10\% bile solution for 10 generations.' whereas it should be 'Bile-resistant Escherichia coli from the strain NCIM 2931 (http://www.ncl-india.org/files/NCIM/CatalogueDetails.aspx?NCIMNo=2931\& menuid $=\mathrm{ql4}$; this strain is internationally available as ATCC 25922) was developed by subculturing it in the aforementioned $10 \%$ bile solution for 10 generations.'

(C) Author(s) (or their employer(s)) 2019. No commercial re-use. See rights and permissions. Published by BMJ.

BMJ Innov 2019;5:65. doi:10.1136/bmjinnov-2017-000209corr1

A) Check for updates 